\title{
PROBLEM TOŻSAMOŚCI W LITERATURZE OKINAWSKIEJ XX WIEKU (NA PRZYKŁADZIE OPOWIADAŃ POSTERUNKOWY UKUMA IKEMIYAGIEGO SEKIHŌ I MATKI, KOBIETY NAKANDAKARI HATSU)
}

\author{
ANNA SPINEK-BOMKE ${ }^{1}$ \\ (Uniwersytet im. Adama Mickiewicza w Poznaniu)
}

Słowa kluczowe: Okinawa - Japonia - literatura - tożsamość

Key words: Okinawa - Japan - literature - identity

\begin{abstract}
Abstrakt: Anna Spinek-Bomke. PROBLEM TOŻSAMOŚCI W LITERATURZE OKINAWSKIEJ XX WIEKU (NA PRZYKŁADZIE OPOWIADAŃ POSTERUNKOWY UKUMA IKEMIYAGIEGO SEKIHŌ I MATKI, KOBIETY NAKANDAKARI HATSU). PORÓWNANIA 18, 2016. T. XVIII. S. 197-217. ISSN 1733-165X. Celem niniejszego artykułu jest przeanalizowanie kwestii poczucia tożsamości narodowej mieszkańców wysp Riukiu oraz sposobu, w jaki problem ten został przedstawiony $\mathrm{w}$ wybranych okinawskich utworach prozatorskich: opowiadaniach Posterunkowy Ukuma Ikemiyagiego Sekihō oraz Matki, kobiety Nakandakari Hatsu. Mieszkańcy królestwa Riukiu, zaanektowanego przez Japonię dopiero w 1879 roku, byli zarówno kulturowo, jak i etnicznie odmienni od Japończyków. Problemy wynikające z ich podwójnej, japońskookinawskiej tożsamości przedstawione są w pierwszym z opowiadań. Głównym tematem powstałych pięćdziesiąt lat później Matek, kobiet są natomiast traumatyczne wspomnienia wojenne bohaterek i ich wpływ zarówno na codzienne życie Okinawczyków, jak i na ich stosunek do mieszkańców „właściwej Japonii” (hondo).
\end{abstract}

Abstract: Anna Spinek-Bomke. THE IDENTITY ISSUE IN OKINAWAN LITERATURE OF THE 20TH CENTURY (ON THE EXAMPLE OF THE SHORT STORIES OFFICER UKUMA IKEMIYAGI SEKIHŌ AND MOTHERS, WOMEN NAKANDAKARI HATSU). COMPARISONS 18,

\footnotetext{
${ }^{1}$ E-mail Address: spinek.anna@gmail.com
} 
2016. Vol. XVIII. P. 197-217. ISSN 1733-165X. The aim of this article is to analyse the feeling of national identity of the Ryukyuans and the way in which this problem is presented in selected Okinawan prose: short stories Officer Ukuma by Ikemiyagi Sekiho and Mothers, Women by Nakandakari Hatsu. Inhabitants of Ryukyu Kingdom, incorporated by Japan only in 1879, were both culturally and ethnically different from the Japanese. Problems originating from their double, Japanese-Okinawan identity are presented in the first of the stories. The main topic of Mothers, Women, written fifty years later, are traumatic wartime memories of the heroines and their influence on both the Okinawans' everyday life and their attitude towards the inhabitants of Japan proper (hondo).

Znajdujący się na południowym krańcu Japonii archipelag, dawniej określany mianem wysp południowych albo południowo-zachodnich (nantō lub nansei shotō), a współcześnie nazywany wyspami Riukiu lub po prostu Okinawą, wyróżnia się na tle innych terytoriów tego kraju. Przez długi czas na Okinawie istniało suwerenne, rozwinięte pod względem cywilizacyjnym królestwo, którego obywatele uważali się za niepodległy naród. Z tego powodu dokonana w 1879 roku przez Japonię aneksja wysp południowych w znaczący sposób wpłynęła na poczucie własnej tożsamości kolejnych pokoleń tamtejszych mieszkańców, stopniowo ulegających coraz silniejszej japonizacji. Problem ich - odrębnej od japońskiej - tożsamości narodowej, w wymiarze indywidualnym i ogólnym, pojawia się w wielu utworach pochodzących z Okinawy pisarzy, jak na przykład w zaprezentowanych w niniejszym artykule opowiadaniach: Ukuma junsa (Posterunkowy Ukuma, 1922), Ikemiyagiego Sekihō (1893-1951) oraz w Haha tachi, onna tachi (Matki, kobiety, 1982) Nakandakari Hatsu (ur. 1950).

\section{Z dziejów relacji okinawsko-japońskich}

Mieszkańcy królestwa Riukiu przez wieki uważani byli przez Japończyków za obcokrajowców. W wydanej w 1712 roku Wakan sansai zue (Ilustrowana encyklopedia japońsko-chińska) Okinawa zaliczona została do „obcych krajów” (ikoku) podobnie jak Chiny, Korea i zamieszkałe przez Ajnów Ezo (Morris-Suzuki 83). Okinawskie zwyczaje, język, a nawet ubiór uchodziły w oczach Japończyków za dziwne. Przywódcy rządzącego hanem ${ }^{2}$ Satsuma rodu Shimazu, którzy podporządkowali sobie królestwo Riukiu w 1609 roku, dbali o to, aby podróżujący do Edo królewscy emisariusze należycie eksponowali swoją odmienność, ukrywając

${ }^{2}$ Han - japońskie księstwo feudalne, zarządzane przez panów feudalnych (daimyō). System hanów istniał od początków XVI wieku do 1871 roku, kiedy to został zastąpiony przez system prefektur (ken). 
jednocześnie te elementy własnej kultury, które były Japończykom zbyt dobrze znane. Satsuma była jedynym hanem, któremu udało się podbić obce państwo i z chęcią wykorzystywała egzotyczność riukiuańskich delegacji do podkreślenia własnej potęgi (Kerr 247).

Japończycy dalecy byli jednak od uznania Okinawczyków za równy im naród, co nie uległo zmianie również po obaleniu w 1872 roku królestwa Riukiu i przyłączeniu w siedem lat później nowopowstałej prefektury Okinawa do terytorium Japonii ${ }^{3}$. Cesarz Meiji (Mutsuhito; 1852-1912, panował 1868-1912) ${ }^{4}$ ogłosił wprawdzie, że Okinawczycy „należą do tej samej rasy (jap. jinshu) [co Japończycy], mają te same zwyczaje i język" (Kerr 363), ale to stwierdzenie nie wpłynęło na faktyczny stosunek jego podwładnych do mieszkańców południowych wysp. Przez piętnaście lat modernizacja nowej prefektury postępowała bardzo powoli, a różnice między nią a resztą Japonii zwiększały się zamiast zmniejszać. Japończycy traktowali Okinawczyków jak gorszy, prymitywny naród. Ci z kolei uważali przybyszy z północy za kolonizatorów, a w powstałych później utworach nieraz opisywali tragizm swojej ówczesnej sytuacji (Morton 256). Okinawczycy, którzy postanowili przeprowadzić się do „właściwej Japonii” (hondo) traktowani byli na równi z burakumin - pogardzanymi wyrzutkami społecznymi (Taira 143). Według George'a Kerra, Japończycy „dyskryminowali w taki sam sposób rdzennych mieszkańców Nahy i Shuri, Miyako i Yaeyamy, Kume i Keramy. Wobec 'kolonialnego traktowania' wszyscy oni byli ‘Okinawczykami'” (Kerr 394).

Dopiero w latach dziewięćdziesiątych XIX wieku, po proklamowaniu pierwszej japońskiej konstytucji i zwycięskiej wojnie z Chinami, rozpoczęto intensywną japonizację Okinawy. Szczególną uwagę zwrócono na edukację, stanowiącą potężne narzędzie $\mathrm{w}$ procesie wychowywania lojalnych obywateli, a zarazem zapewniającą rządzącym pośredni wpływ na prawie każdą okinawską rodzinę. Uczniowie zmuszeni zostali do obcięcia włosów i noszenia nowoczesnych fryzur, a nauczyciele - do zastąpienia tradycyjnych strojów uniformami pracowników rządowych. W szkolnych klasach zawieszono portrety cesarza i cesarzowej. Sugestie dotyczące wprowadzenia do programu nauczania lokalnej historii zostały, rzecz jasna, zignorowane (Kerr 414-416).

Okinawczycy nieraz dobrowolnie poddawali się japonizacji, widząc $w$ niej szansę na wtopienie się w społeczeństwo, a przez to na uniknięcie dyskryminacji.

${ }^{3}$ W 1872 roku król Riukiu, Shō Tai (1843-1901) został mianowany przez japońskiego cesarza władcą hanu Riukiu. Dwudziestego siódmego marca 1879 roku w miejsce hanu ustanowiono prefekturę (jap. ken) Okinawa, a króla zmuszono do abdykacji.

${ }^{4}$ Cesarz Meiji - według japońskiej tradycji 122. cesarz Japonii. Za jego panowania (i.e. w okresie Meiji) doszło do obalenia feudalizmu, zniesienia siogunatu i przywrócenia realnej władzy cesarza nad państwem, a także nawiązania oficjalnych kontaktów z obcymi krajami, w tym z państwami Europy Zachodniej i Stanami Zjednoczonymi. 
Nie na wiele się to jednak zdało. Jeszcze na początku lat dwudziestych XX wieku studenci pochodzący z Okinawy spotykali się z brakiem akceptacji na pensjach, a turyści bywali dyskryminowani w hotelach. Pracodawcy nie zatrudniali Okinawczyków na takich samych zasadach, jak mieszkańców innych prefektur. Rządowi udało się doprowadzić do tego, że Okinawczycy uważali się za japońskich obywateli, ale „niewiele zrobiono w celu przezwyciężenia rozpowszechnionego wśród Japończyków poczucia wyższości nad Okinawczykami uważanymi za 'zewnętrzną grupę', mniejszość drugiej kategorii, kuzynów ze wsi' (Kerr 448).

Jednocześnie jednak - zwłaszcza w gronach akademickich - zaczęto uwypuklać związki wysp Riukiu z Japonią. Jednym z punktów przełomowych było podbicie przez Japończyków Tajwanu w 1895 roku. Zauważono wówczas, że riukiuańskie tradycje „były dziwne, z pewnością, ale nie aż tak dziwne i trudne do zrozumienia jak mowa, ubrania i zwyczaje Chińczyków z Formozy [...]" (Kerr 423). Japońscy naukowcy, stopniowo zapoznający się z europejskimi pismami i teoriami, zainteresowali się koncepcją rasy, zastąpionej następnie pojęciem "grupy etnicznej" (jap. minzoku). Rozgorzały dyskusje na temat powiązań Japończyków z innymi azjatyckimi ludami, w tym z Okinawczykami (Morris-Suzuki 87).

Po raz pierwszy wyspy Riukiu wzbudziły naukowe zainteresowanie. Iha Fuyū (1876-1947), nazywany "ojcem okinawistyki”, oraz etnolog Yanagita Kunio (1875-1962) podkreślali w swoich pracach kulturową i etniczną homogeniczność (jap. dōshitsusei) obu ludów, a wypracowane przez nich poglądy nazwano później "teorią wspólnych przodków Riukiu i Japonii" (jap. nichiryū dōsoron; Takahashi 169). W pracach Yanagity K. można dostrzec wpływ zachodniej koncepcji rozwoju cywilizacyjnego jako przechodzenia danej grupy etnicznej przez określone etapy ewolucji. Różnice między Japonią a Okinawą były więc - w myśl tej teorii - związane nie z przestrzenią, lecz z czasem. Innymi słowy, Okinawczycy nie tylko przestali być uważani za mieszkańców "obcego państwa", ale także uznano, że "zawsze byli Japończykami, którzy pozostali po prostu we wcześniejszym stadium historycznej ewolucji" (Morris-Suzuki 91).

Założenia teorii Thy i Yanagity zaczęły być krytykowane po zakończeniu wojny na Pacyfiku w 1946 roku. Przez stulecia największy wpływ na riukiuańską architekturę, naukę, zwyczaje i myślenie o świecie miała bowiem nie Japonia, a Chiny. Arystokraci kształcili się w klasycznych chińskich tekstach, książęta nosili stroje w stylu dynastii Ming, a spragnieni wiedzy uczniowie udawali się do Państwa Środka, gdzie pozwolono im bezpłatnie studiować. Dzięki kontaktom handlowym z odległymi mocarstwami do riukiuańskiej kultury przeniknęło także wiele elementów odróżniających ją od kultury japońskiej. Płótno kasuri ${ }^{5}$, którego

${ }^{5}$ Kasuri (indon. ikat) - rodzaj płótna powstałego poprzez przeplatanie ze sobą farbowanych (najczęściej na kolor indygo) i białych nici, tak aby stworzyć lekko rozmazany, jasny wzór na ciemnym tle. 
tkanie Okinawczycy opanowali do perfekcji, zostało importowane z Indii. Technikę batikowania materiałów przywieziono z Javy i Sumatry. Tradycyjne nakrycia głowy noszą ślady wpływów malajskich (Kerr 94-95), a prototypy smoczych kolumn z królewskiego zamku Shuri można odnaleźć w Kambodży i Tajlandii (Kerr 109).

Oczywiście kultura japońska również wywarła na Okinawę niemały wpływ. Bliskość geograficzna ułatwiała wzajemny handel, a inwazja hanu Satsuma znacząco wzmocniła więzi między oboma państwami. Arystokracja pozostawała pod silnym wpływem Chin, ale życie na wsi zdecydowanie bardziej przypominało model japoński (Kerr 167). Popularne rozrywki, takie jak tańce i piosenki, przenikały między Japonią a Okinawą (Kerr 195). Riukiuańczycy przyjęli także japońskie pismo sylabiczne (jap. kana) i, uznając za bardziej praktyczne niż skomplikowane chińskie znaki, ustanowili je oficjalnym systemem zapisu, służącym nawet do tworzenia dokumentów państwowych. Spróbowano również powiązać rodziny królewskie obu państw. Według skompilowanej w 1650 roku kroniki Chüzan seikan (Zwierciadło wieków królestwa Chūzan) ojcem Shuntena (1166?-1237), pierwszego historycznego władcy Okinawy, miał być Minamoto no Tametomo (1139-1170), jeden z dalekich potomków cesarza Kanmu (737-806; panował 781-806). Takahashi Takayo pisze:

...teoria wspólnych przodków Riukiu i Japonii związana jest z historycznym faktem zaanektowania królestwa Riukiu przez Japonię. Nie wiadomo, czy gdyby Riukiu było niepodległym państwem, teoria ta nie straciłaby na sile, nie rozwijając się do tego stopnia. Co więcej, jeżeli [królestwo Riukiu] zostałoby zaanektowane nie przez Japonię, a przez Chiny, to - aby to usprawiedliwić - być może uwypuklano by te elementy kultury okinawskiej, które pozostawały pod wpływem kontynentu i dowodzono by jej jedności z kulturą chińską. (Takahashi 190)

Autor przytoczonego fragmentu stwierdza również, że na terenach wysp Riukiu istniało rozwinięte cywilizacyjnie królestwo, o stosunkowo dużej gęstości zaludnienia, którego mieszkańcy trudnili się nie tylko zbieractwem i łowiectwem, ale różnorodnymi zajęciami, $\mathrm{w}$ tym rolnictwem i handlem zagranicznym. Trudno określić taki naród jako „aborygenów” (jap. kyūdojin) - przekonuje.

Odrębnym problemem jest kwestia pochodzenia mieszkańców Okinawy i ich pokrewieństwa z Japończykami. Według współczesnych badań archeologicznych prahistoryczni Okinawczycy zostali odgrodzeni od reszty świata już pod koniec plejstocenu (ok. 38000-10000 r. p.n.e.), podczas gdy najstarsi przodkowie Japończyków przybyli na tereny dzisiejszej Japonii dopiero około 2300 roku p.n.e.. Obie grupy żyły osobno przez trzydzieści tysięcy lat, były więc "fizycznie i kulturowo czyli etnicznie - odrębne" (Taira 145). Fala przybyszy z północy - uciekających przed trwającą w Japonii wojną domową - pojawiła się na Okinawie dopiero w XII wieku (Pearson 108). Można więc uznać, że wspólne korzenie Japończyków 
i Okinawczyków są prawie równie odległe jak w przypadku innych azjatyckich narodów.

Problematyka języka bądź dialektu okinawskiego jest ściśle powiązana z badaniami nad pochodzeniem mieszkańców wysp Riukiu. $Z$ racji ożywionego handlu między Okinawą a Kiusiu w okresie yayoi (ok.400 r. p.n.e. - 250 r. n.e.) można przypuszczać, że tamtejsze języki również ulegały wówczas wzajemnym wpływom. Kontakty między wyspami - a wraz z nimi wymiana językowa - osłabły z nadejściem okresu kofun (ok. 250-710 r. n.e.; Taira 145-146). Z socjolingwistycznego punktu widzenia przybysze z Półwyspu Koreańskiego, którzy podbili lub zasymilowali dotychczasowe ludy zamieszkujące Japonię, musieli przynieść ze sobą nowe języki. Język japoński stanowiłby więc mieszaninę kilku języków, z których zaledwie jedna grupa byłaby spokrewniona $\mathrm{z}$ językiem okinawskim (Maher 31-33). Znajduje to swoje odzwierciedlenie w rzeczywistości. Cesarscy urzędnicy, którzy przypłynęli na Okinawę pod koniec XIX wieku, "mogli konwersować z wykształconymi przywódcami w Shuri i Naha, ale nie byli w stanie sprawić, żeby rozumiano ich na wsi" (Kerr 412). Incydenty z czasów bitwy o Okinawę (03.04.1945-16.06.1945), kiedy to japońscy żołnierze zabijali rozmawiających w lokalnych dialektach autochtonów podejrzewając ich o szpiegostwo, również dowodzą trudności we wzajemnym zrozumieniu obu grup. Michael Molasky przywołuje także przypadek okinawskiego filmu z 1989 roku, który w pozostałych częściach Japonii wyświetlany był z napisami i stwierdza, że dla Japończyka dialekty języka okinawskiego są mniej zrozumiałe niż język portugalski dla Hiszpana (Molasky, Rabson 8, 32).

Najnowsze badania nad etnicznym i kulturowym pokrewieństwem Japończyków i Okinawczyków spotykają się coraz częściej z pozytywnym przyjęciem ze strony tych drugich. Mieszkańcy wysp Riukiu, rozczarowani postawą Japończyków podczas bitwy o Okinawę oraz po zakończeniu wojny na Pacyfiku nie pragnęli już dowieść ich wspólnych korzeni. Ponowne przyłączenie do terytorium Japonii, w którym upatrywali szansy na wyzwolenie się spod amerykańskich rządów, zawiodło ich oczekiwania. Główny problem - obecność amerykańskich żołnierzy, których bazy wojskowe zajmują znaczną część wyspy - pozostał nierozwiązany. Być może dlatego Okinawczycy postanowili odkryć własną tożsamość narodową - tym razem bez obawy przed dyskryminacją, ale z dumą i zadowoleniem ze swojej unikatowości (Taira 159-167).

\section{Współczesna literatura okinawska}

Współczesna literatura okinawska zaczęła rozwijać się kilkadziesiąt lat później niż japońska, której początki datuje się już na pierwsze lata okresu Meiji. Było to przede wszystkim spowodowane licznymi katastrofami naturalnymi, które na- 
wiedziły wyspy Riukiu w XIX wieku i wpędziły ich mieszkańców w skrajną biedę. Dopiero w latach dwudziestych XX wieku Okinawczycy, nie musząc już koncentrować wszystkich sił na walce o przetrwanie, mogli poświęcić czas na zapoznanie się z nowymi gatunkami literackimi i spróbować zastosować je w praktyce. Zrezygnowali wówczas $\mathrm{z}$ tradycyjnych form ekspresji: wierszy wzorowanych na starożytnych poematach ze zbioru Omoro sōshi (Zapiski myśli, 1532-1623), riukiuańskich pieśni czy przedstawień kumi wudui ${ }^{6}$. Zaczęli pisać głównie w standardowym języku japońskim, jedynie sporadycznie wzbogacając tekst o okinawskie wyrażenia (Kawamura 252). Pod względem formy ówczesne utwory były wzorowane na literaturze zachodniej. Opowiadanie, wcześniej nieznany gatunek prozy, zaczął cieszyć się dużą popularnością.

$\mathrm{Z}$ drugiej strony $\mathrm{w}$ większości dzieł pisarze poruszali zagadnienia ściśle związane z sytuacją panującą na Okinawie. Często wykorzystywali motywy dyskryminacji i poczucia niższości względem Japończyków pochodzących z głównych wysp, a także problemów wynikających z podwójnej, japońsko-riukiuańskiej tożsamości o cechach - jak to niekiedy się określa - „dwuwarstwowości” (jap. Nijūsei; Kawamura 255). Ta problematyka jest typowa dla pisarzy takich jak Yamashiro Seichū (1884-1949), Ikemiyagi Sekihō, Kushi Fusako (1903-1986) czy Yamanokuchi Baku (1903-1963). Niektórzy twórcy odcinali się od tej tematyki. Na przykład poeci Nakamura Kare (1905-1951) i Tsukayama Issui (1905-1981) próbowali tworzyć utwory stricte modernistyczne, jednak ich wiersze nie były równie popularne i doceniane jak osadzona głęboko $w$ riukiuańskich realiach poezja Yamanokuchiego.

Pod koniec lat trzydziestych XX wieku literaturę okinawską dotknął kryzys, który trwał nawet po zakończeniu wojny na Pacyfiku. Renesans nastąpił dopiero w połowie lat pięćdziesiątych. Studenci Uniwersytetu Riukiuańskiego (Ryūkyū Daigaku) zaczęli wówczas wydawać lewicujące czasopismo „Ryūdai bungaku” (Literatura Uniwersytetu Riukiuańskiego), które na krótko stało się najważniejszym lokalnym magazynem literackim. Jego redaktorzy więcej miejsca poświęcali jednak teoretycznym debatom na temat roli literatury niż na publikowanie i promowanie nowych utworów. W dodatku akceptowali jedynie określone tematy i sposoby przedstawiania świata, zawężając grono potencjalnych autorów i czytelników. Założone w 1966 roku liberalne czasopismo "Shin Okinawa bungaku” (Nowa literatura okinawska) szybko stało się więc głównym magazynem literackim Okinawy. Publikowano w nim utwory o szerokim, częściowo do dziś aktualnym spectrum zagadnien. To w tym czasopiśmie ukazało się opowiadanie Kakuteru pāti (Przyjęcie koktajlowe, 1967) autorstwa Ōshiro Tatsuhiro (ur. 1925), który w 1967 roku otrzymał za nie Nagrodę Akutagawy - jako pierwszy Okinawczyk w dziejach tego prestiżowego wyróżnienia literackiego (Molasky, Rabson 4-6).

${ }^{6}$ Kumi wudui (jap. kumi odori) - rodzaj tradycyjnego okinawskiego przedstawienia, zazwyczaj przypominającego operetkę, łączącego w sobie muzykę, taniec i sztukę teatralną. 
Do roku 1972, a więc do ponownego przyłączenia prefektury Okinawa do Japonii, wojna i okupacja amerykańska były dominującymi tematami nowo powstających utworów. Ich autorzy chętnie poruszali problemy przestępczości wśród żołnierzy. Portretowali także dezerterów lub prostytutki mieszkające $\mathrm{w}$ dzielnicach sąsiadujących z amerykańskimi bazami (Kawamura 257). Wojenna tematyka była podejmowana również po 1972 roku, ale ponowne przyłączenie Okinawy do Japonii stało się pretekstem do powrotu do rozważań na temat tożsamości i własnego miejsca $\mathrm{w}$ japońskim społeczeństwie. Uwagę wielu pisarzy okinawskich trzeciej generacji zajmował problem relacji z Japończykami czy wciąż obecnymi na wyspach Amerykanami.

W latach osiemdziesiątych ubiegłego wieku swoje utwory po raz pierwszy zaczęło publikować wiele utalentowanych kobiet, takich jak Sakiyama Tami (ur. 1954), Nakawaka Naoko (ur. 1948), Yamanoha Nobuko (ur. 1941), Yoshida Sueko (ur. 1947) czy Nakandakari Hatsu (ur. 1950). Niektóre z nich poruszały problematykę tożsamości, ale zajmowały je także inne, zróżnicowane tematy.

Wyjątkowo pomyślne dla riukiuańskich literatów okazały się lata dziewięćdziesiąte. W 1996 roku Matayoshi Eiki (ur. 1947) otrzymał Nagrodę Akutagawy za opowiadanie Buta no mukui (Zapłata świni, 1996). Krytycy próbowali początkowo zdyskredytować wybór kapituły, sugerując, że - ze względu na ówczesne zażarte dyskusje na temat amerykańskich baz wojskowych na Okinawie - jurorzy kierowali się względami politycznymi. Zmienili jednak zdanie, kiedy w następnym roku nieoczekiwanie nagrodzono opowiadanie Suiteki (Krople wody, 1997) autorstwa innego pisarza z wysp Riukiu, Medorumy Shuna (ur. 1960; Molasky, Rabson 1-7). Mimo że utwór Krople wody powstał ponad pięćdziesiąt lat po tragicznej bitwie o Okinawę, wojenne wspomnienia i dręczące bohatera poczucie winy stanowią istotny element fabuły opowiadania. Obaj laureaci Nagrody im. Akutagawy pozostają wciąż jednymi z najbardziej płodnych i popularnych pisarzy okinawskich.

\section{Ikemiyagi Sekihō, Posterunkowy Ukuma. Między okinawskością a japońskością}

Ikemiyagi Sekihō urodził się w Naha, stolicy prefektury Okinawa - a dokładniej w dzielnicy Kume, zamieszkanej tradycyjnie przez potomków chińskich rzemieślników i urzędników, przybyłych na wyspy Riukiu z rozkazu cesarza w 1393 roku (Kerr 75). Po ukończeniu miejscowej szkoły wyjechał do Tokio, gdzie podjął studia anglistyczne na Uniwersytecie Waseda (Waseda Daigaku). W 1916 roku wrócił na Okinawę. Pracował wówczas jako nauczyciel języka japońskiego i dziennikarz prasowy, a także publikował w lokalnej gazecie tłumaczenia zagranicznych utworów oraz autorskie opowiadania. Dużo podróżował po ojczystej 
wyspie, komponując wiersze. Po kilku latach ponownie wyjechał do Tokio, żeby kontynuować działalność pisarską. Największą sławę przyniosło mu wydane w 1931 roku Ryūkyū rekishi monogatari (Opowieści historyczne z wysp Riukiu; Okamoto, Takahashi 50). Wcześniej, w 1922 roku, Ikemiyagi opublikował także opowiadanie Posterunkowy Ukuma, które obecnie stanowi cenne źródło wiedzy o życiu na Okinawie w latach dwudziestych ubiegłego wieku.

Tytułowy bohater Posterunkowego Ukumy, Ukuma nu Hiyākū, to Okinawczyk $\mathrm{z}$ „dość osobliwej wioski X [zamieszkiwanej] przez potomków chińskich osadników" (Ikemiyagi 51). Autor najprawdopodobniej ma na myśli Kume, będącą jedyną udokumentowaną chińską osadą na Okinawie (Molasky, Rabson 58). Kwestia pozycji społecznej mieszkańców wioski jest nieco problematyczna. Opisani przez Ikemiyagiego wieśniacy wykonują "mało poważane prace i przez mieszkańców innych dzielnic Nahy określani są pogardliwie jako 'ci z X'" (Ikemiyagi 51). Tymczasem Chińczycy z Kume, tworzący elitę intelektualną królestwa Riukiu, przez wieki cieszyli się powszechnym szacunkiem i przywilejami godnymi szlachty. Nawet kiedy zrezygnowali z tradycyjnego ubioru i fryzur, przejmując bardziej riukiuański styl życia, nie zapomniano o ich szczególnym pochodzeniu (Kerr $75-76,178)$. Sytuacja finansowa mieszkańców Kume zaczęła pogarszać się na początku XIX wieku, ale swoją uprzywilejowaną pozycję utracili oni dopiero po roku 1879. Kume, tradycyjnie związane z Chinami, stało się wówczas centrum antyjapońskim, nie zasługiwało więc na rządowe wsparcie (Kerr 373). W nowej rzeczywistości przestała być też przydatna znajomość klasycznych tekstów chińskich, którą szczycili się mieszkańcy wioski. Mimo to ludzie pochodzący z Kume nie byli powszechnie pogardzani. $Z$ oznakami poniżenia spotykali się raczej jedynie ze strony niechętnych tej osadzie Japończyków.

Wieśniacy z wioski $X$ znajdują się w o wiele gorszej sytuacji. Nie są bynajmniej uczonymi, specjalizującymi się $\mathrm{w}$ starochińskich tekstach. Wręcz przeciwnie, trudnią się podrzędnymi, mało poważanymi zajęciami: łowieniem ryb, łapaniem żab czy wyplataniem kapeluszy. Zarobione pieniądze wystarczają im jedynie na zaspokojenie podstawowych potrzeb i prowizoryczny, grupowy fundusz ubezpieczeniowy. Władze nie interesują się warunkami życia, jakie panują w wiosce. Ich obojętność ukazana jest wyraźnie w scenie przemowy Hiyākū, kiedy to wieśniacy przekonani są, że otrzymają od rządzących „jakąś pomoc, która poprawiłaby warunki ich życia. Obniżenie podatków, remont dróg albo bezpłatną opiekę medyczną..." (Ikemiyagi 53-54). Ich nadzieje okazują się płonne, a sam fakt, że przyszły im do głowy właśnie takie myśli, wskazuje na to, w jak trudnych warunkach przyszło im żyć. Narrator stwierdza wprawdzie, że mieszkańcy wioski $X$ nie uważają swojego życia za szczególnie ciężkie, ale zarówno ich rozczarowanie brakiem jakiegokolwiek wsparcia władz, jak i ich wcześniejsza radość z sukcesu Ukumy, któremu udaje się wyrwać z ubogiej wioski, dowodzą tego, iż w rzeczywistości zdawali sobie sprawę $\mathrm{z}$ beznadziei własnego położenia. 
Dzięki osadzeniu akcji opowiadania $\mathrm{w}$ tak specyficznym miejscu autorowi udaje się poruszyć problematykę tożsamości już w pierwszych zdaniach utworu. Mieszkańcy Kume są ponoć potomkami chińskich osadników, ale próżno w ich życiu doszukiwać się jakichkolwiek pozostałości chińskiej kultury. Bohaterowie ani razu nie wspominają o swoich przodkach z kontynentu, więc można uznać, że nie czują się $\mathrm{z}$ nimi szczególnie związani. Tymczasem $\mathrm{w}$ oczach pozostałych Okinawczyków wieśniacy ci są nadal przybyszami z obcego kraju, stanowiącymi odrębną, zamkniętą grupę etniczną. Nawet porzucenie starych zwyczajów i próby upodobnienia się do kolegów-Japończyków nie pozwalają młodemu Ukumie Hiyākū pozbyć się pogardliwego przydomka "ten z X".

Tytułowy bohater opowiadania Ikemiyagiego na własnej skórze przekonuje się, jak bolesne może okazać się poszukiwanie własnej tożsamości kulturowej. Przez lata był cichym, spokojnym chłopcem, niczym niewyróżniającym się spośród innych wieśniaków. Przypuszczalnie pracował razem z nimi na polu, a wieczory spędzał na wspólnych tańcach i śpiewach. Zapragnął jednak zostać policjantem - być może mając dość biedy, ciężkiej pracy i pogardliwego traktowania, z którym dotychczas musiał się mierzyć. Rodzice Ukumy (a nawet współmieszkańcy wioski) robili wszystko, co mogli, aby pomóc mu spełnić to marzenie. Ówczesne okinawskie rodziny były - jak pisze G. Kerr - gotowe na każde poświęcenie, by zapewnić obiecującym młodzieńcom edukację, a wieśniacy byli dumni z młodych mężczyzn, którzy mieli ambicję przystępować do egzaminów urzędniczych (Kerr 412). Można powiedzieć, że przedstawiona w opowiadaniu Posterunkowy Ukuma sytuacja idealnie odzwierciedla riukiuańską rzeczywistość.

Zdanie egzaminu i otrzymanie wymarzonej posady posterunkowego paradoksalnie stało się początkiem problemów Hiyākū. Dopiero teraz zaczął uzmysławiać sobie przepaść między ubogą, prymitywną wręcz wioską a centrum Nahy. Ukuma zapragnął więc upodobnić się do kolegów z pracy, pozbywając się swojej chińsko-okinawskiej tożsamości. Wierząc, że skrupulatne wykonywanie służbowych obowiązków zapewni mu awans, a więc i lepszą, bardziej dostatnią przyszłość, zapomniał o lojalności względem sąsiadów. Mieszkańcy wioski sądzili, że zajęcie zaszczytnego stanowiska przez jednego z nich przyczyni się do polepszenia jakości ich życia. Tymczasem Hiyākū nie tylko nie okazał żadnej pomocy rodzinnej osadzie, ale wręcz zaczął narzekać na jej mieszkańców. Drażniły go rzeczy, na które wcześniej w ogóle nie zwracał uwagi: wszechobecny brud, głośne zabawy w nocy, nagość pracujących wieśniaków. Ludziom z X nie przeszkadzał nieporządek, a wieczorne przyjęcia były dla nich głównym źródłem radości i poczucia wspólnoty. Nie potrafili pogodzić się z tym, że chłopiec, którego zawsze lubili i wspierali, nagle zaczął wymagać od nich przestrzegania przepisów prawnych i grozić im stosownymi do przewinienia karami. Zaczęli więc unikać młodego Ukumy, który czuł się coraz bardziej wyobcowany. Można powiedzieć, że w pewnym sensie osiągnął zamierzony cel: przestał być członkiem wspólnoty z wioski X. 
Nie zważając na onieśmielenie rodziny, Hiyākū zapraszał nowych znajomych do domu i spędzał z nimi coraz więcej czasu. Często ubierał się w podkreślający jego status społeczny mundur posterunkowego. Mimo to nie udało mu się zdobyć pełnej akceptacji współpracowników. Niezależnie od tego, jak bardzo starał się do nich upodobnić, wciąż był uważany za "tego z X". Stopniowo Ukuma uświadamiał sobie daremność swojego wysiłku. W dodatku od czasu do czasu sam czuł, że nie potrafi porozumieć się z kolegami z pracy. Pochodzili oni nie z Okinawy, lecz $\mathrm{z}$ „prefektur Kagoshima, Saga albo Miyazaki i zarówno ich mentalność, jak i środowisko, w którym do tej pory żyli znacząco odróżniały ich od Hiyākū. Mógł pijać z nimi awamori7 i głośno się bawić, ale nie szczerze, od serca, porozmawiać" (Ikemiyagi 55). Młodemu Ukumie zdarzało się nawet nazywać ich w myślach obcokrajowcami, co dość dobrze obrazuje stosunek ówczesnych Okinawczyków do Japończyków.

Zmagania Ukumy z własną tożsamością i jego próby zjaponizowania samego siebie zakończyły się klęską. Przestał identyfikować się ze współmieszkańcami wioski, ale nie udało mu się nawiązać bliższych relacji ze znajomymi z pracy. Ostatecznie został więc zupełnie sam - pozbawiony zarówno przyjaciół, jak i poczucia przynależności do jakiejkolwiek grupy etnicznej, rozdarty między dwoma odmiennymi światami.

Wobec tej sytuacji trudno się dziwić, że Hiyākū tak mocno przywiązał się do jedynej osoby, która okazywała mu szczerą życzliwość - do nastoletniej prostytutki, Małej Kamarū. W pozornie odmiennych historiach obojga bohaterów można odnaleźć pewne cechy wspólne. Pochodzili oni z rodzin od lat mieszkających na Okinawie. Zarówno Ukuma, jak i Kamarū dobrze znali smak biedy (choć dziewczyna z pewnością pamiętała jeszcze spędzone w dostatku dzieciństwo). Oboje, choć z różnych powodów, uskarżali się na brak szacunku innych ludzi. Hiyākū był pogardzany ze względu na swoje pochodzenie, a jednocześnie musiał zmagać się z niechęcią sąsiadów z wioski. Kamarū natomiast, jako prostytutka należąca do najniższej klasy społecznej, oficjalnie traktowana była na równi z żebrakami czy wędrownymi grajkami (Kerr 190). Przede wszystkim jednak oboje czuli się samotni: Ukuma niejako na własne życzenie, $\mathrm{w}$ wyniku zerwania więzi z rodzinną wioską, Kamarū zaś - z powodu przymusowego odizolowania od brata i zamieszkania z obcymi jej ludźmi. Wszystko to sprzyjało zbliżeniu się bohaterów do siebie i zbudowaniu szczerej, pełnej głębokiego zaufania relacji.

Związek z Małą Kamarū mógł okazać się dla Ukumy zbawienny. Dziewczyna nie musiała błądzić $w$ poszukiwaniu własnej tożsamości. Urodziła się na Okinawie, w stosunkowo zamożnej rodzinie, z którą nigdy nie przestała czuć się związana. Nawet winą za sprzedanie jej do domu publicznego obarczała nie niezbyt bystrego starszego brata, a „złych ludzi”, którzy wykorzystali jego naiwność i do-

\footnotetext{
${ }^{7}$ Awamori - tradycyjna okinawska wódka ryżowa.
} 
prowadzili go do bankructwa. Kamarū doskonale wiedziała więc, kim jest i skąd pochodzi. Jednocześnie jednak, utraciwszy swoją dawną pozycję społeczną, nie żywiła do Hiyākū żadnych uprzedzeń z racji jego pochodzenia. Gdyby ich romans przeistoczył się $\mathrm{w}$ trwały związek, być może Ukumie łatwiej byłoby uporać z nękającymi go problemami.

Nakahodo Masanori zwraca szczególną uwagę na występujący w opowiadaniu motyw munduru. Ubrany w służbowy strój Ukuma zdaje się stawać innym człowiekiem, odizolowanym od reszty ludzi. Dziewczęta z wioski, zobaczywszy go w nim po raz pierwszy, wpatrują się w Hiyākū "z podziwem i bojaźnią" Ikemiyagi 52). Z czasem mundur zaczyna symbolizować władzę, którą Ukuma próbuje wykorzystywać, by zmienić oblicze rodzinnej osady. W tym kontekście szczególnego znaczenia nabiera krótkie zdanie poprzedzające opis groźnego tajfunu: „Tego wieczoru na komendzie Hiyākū przebrał się z munduru w kimono i poszedł do domu Kamarū" (Ikemiyagi 59). Ta pozornie banalna czynność dowodzi wyjątkowości uczuć, jakimi Ukuma darzył dziewczynę. Zdawał sobie sprawę z tego, że jest przez nią całkowicie akceptowany i mógł zdobyć się na odwagę, aby odwiedzić ją nie jako władczy policjant, ale jako nieco zagubiony Ukuma nu Hiyākū (Masanori 52-53).

Osiągnięcie szczęścia przez bohaterów uniemożliwiała sytuacja finansowa Ukumy, który zarabiał tak mało, że nawet jego nieprzyzwyczajona do zbytku matka z trudem ukryła rozczarowanie, kiedy przyniósł do domu pierwszą pensję. W dodatku wszystkie zarobione pieniądze Ukuma przekazywał rodzicom. Dopiero z czasem zaczął potajemnie wspomagać finansowo również Kamarū, ale były to niewielkie kwoty niewystarczające na jej wykupienie. Zresztą za pensję posterunkowego nie mógłby utrzymać ich obojga. Zdesperowany mężczyzna chwilami myślał nawet o kradzieży pieniędzy, gdyby tylko dzięki temu mógł żyć szczęśliwie z ukochaną.

Jeszcze jedną, najważniejszą przeszkodą okazał się dylemat tożsamości Ukumy, który pozostawał rozdarty pomiędzy japońskością a okinawskością, surowością ambitnego posterunkowego a wpojoną mu przed laty łagodnością. Pragnienie doskonałego wypełniania służbowych obowiązków, a być może również nadzieja na awans i podwyżkę umożliwiającą mu rozpoczęcie wspólnego życia z ukochaną, wyzwoliły w nim bezwzględną determinację, która skłoniła go do aresztowania ubogiego, podejrzanego o drobną kradzież mężczyzny. Radość Hiyākū ze złapania pierwszego w życiu przestępcy prysła, kiedy okazało się, że schwytany człowiek jest $\mathrm{w}$ rzeczywistości owym mało bystrym bratem Małej Kamarū. Ukuma ze złością myślał o własnym zadowoleniu ze złapania złodzieja i przeklinał samego siebie za to, że tak bezdusznie zaciągnął tego mężczyznę na komisariat.

W ostatniej scenie opowiadania Posterunkowy Ukuma sierżant Watanabe wydaje Hiyākū rozkaz przyprowadzenia siostry oskarżonego, co wprawia Ukumę 
w przerażenie. Czytelnik może jedynie domyślać się, jak potoczyły się dalsze losy bohaterów. Nietrudno wyobrazić sobie reakcję Małej Kamarū na wiadomość, że człowiek, którego obdarzyła największym zaufaniem, jest sprawcą nieszczęścia jej brata. Hiyākū znów, tym razem wbrew własnym intencjom, stanął po stronie obcych, Japończyków, uciskając jednocześnie swoich krajan. Wewnętrzny konflikt Ukumy spowodował zapewne rozpad związku, z którym wiązał nadzieję na osiągnięcie upragnionego spokoju ducha.

\section{Nakandakari Hatsu, Matki, kobiety. Wpływ wojennych doświadczeń na życie i poglądy Okinawczyków}

Nakandakari Hatsu (właściwie Goya Hatsue) urodziła się trzeciego maja 1950 roku w okinawskim mieście Urasoe. Karierę literacką rozpoczęła w latach osiemdziesiątych. Jej pierwszym uznanym utworem było opowiadanie Yakusoku (Przysięga, 1981), za które otrzymała dziewiątą Nagrodę Gazety Riukiuańskiej dla Najlepszego Opowiadania (Ryūkyū Shinpō Tanpen Shōsetsu Shō). Do najważniejszych dzieł tej pisarki zaliczane są również opowiadania Matki, kobiety, Tabibito (Podróżnik, 1983) oraz Chinjō (Oświadczenie, 1989; Honda 86). Pierwsze z nich, wyróżnione ósmą Nagrodą Nowej Literatury Okinawskiej (Shin Okinawa Bungaku Shō), chociaż powstało dokładnie sześćdziesiąt lat później niż Posterunkowy Ukuma, też poświęcone jest poczuciu tożsamości kulturowej. W Matkach, kobietach problematyka ta nie jest jednak równie mocno zaakcentowana. Stosunek Okinawczyków do ich rodaków z "głównych wysp" (i vice versa) daje się bowiem zaobserwować jedynie $\mathrm{w}$ pojedynczych scenach, krótkich spostrzeżeniach bohaterów czy używanych przez nich (i narratora) określeniach.

Oś opowiadania Matki, kobiety wyznacza wątek antywojenny. Starsi bohaterowie wciąż pamiętają bitwę o Okinawę i nie potrafią pogodzić się z odejściem tych, którzy w niej zginęli. Japońskie Siły Samoobrony (Jieitai), przez wielu wyspiarzy uważane za regularne wojsko, wywierają istotny wpływ na decyzje i zachowanie Okinawczyków. Co ciekawe, sami żołnierze ani razu nie pojawiają się na kartach opowiadania; występują jedynie w rozmowach mniej lub bardziej niechętnych im cywilów.

Głównymi bohaterkami utworu są dwie dwudziestopięcioletnie kobiety: Misa i Kazuko. Za czasów szkolnych dziewczęta były dobrymi przyjaciółkami, obdarzonymi bardzo podobnymi charakterami. Z czasem jednak cicha, zamknięta w sobie i melancholijna Misa nieco zgorzkniała (zapewne pod wpływem regularnych docinków rodziny na temat jej samotności), Kazuko zaś całym sercem zaangażowała się w działalność związków zawodowych, dzięki czemu przemieniła się w energiczną, pewną siebie trzpiotkę. Dziewczęta utraciły wspólny język i oddaliły się od siebie, mimo że obie podjęły pracę w tym samym miejscu i widywały 
się, na co dzień. Narrator opisuje na przemian historie Misy i Kazuko - odmienne, a jednak ściśle ze sobą powiązane.

Punktem wyjścia akcji jest awantura, jaką rozpętuje w lokalnym urzędzie babcia Kamado. Jej zachowanie zmusza bohaterki do rozmyślań, przywołuje wspomnienia i stanowi jedno z głównych źródeł antywojennego nastawienia obu dziewcząt.

\section{Historia babci Kamado}

Czytelnik poznaje historię milczącej, zamkniętej w sobie babci Kamado stopniowo, wraz z głównymi bohaterkami. Początkowo dowiaduje się tylko, że babcia przyszła do urzędu gminy i zrobiła tam coś dziwnego, godnego uwagi (jap. mimono - dosł. „rzecz do obejrzenia”). Przybiegła do urzędu boso, w przypominającym pidżamę kimonie i jedynymi słowami, jakie powtarzała, było: „Nie pozwólcie żołnierzom Yamato wejść na moje pole!" (Nakandakari 253). Okazuje się, że staruszka wpadła w obłęd, kiedy usłyszała, że żołnierze Sił Samoobrony mają pomagać jej w żniwach.

Początkowo babcia traktowana jest jedynie jak atrakcja urozmaicająca nudne, poniedziałkowe przedpołudnie. Szybko jednak rozbawienie obserwatorów ustępuje miejsca współczuciu. Kazuko i jej koledzy ze związku postanawiają samodzielnie zająć się żniwami na polu staruszki, mając nadzieję, że dzięki temu babcia odzyska spokój ducha. Matka Misy postanawia zaś zaopiekować się chorą sąsiadką. Po krótkim czasie babcia Kamado istotnie zamieszkuje z Misą i jej matką, co daje dziewczynie szansę zbliżenia się do staruszki i poznania jej smutnej historii. Okazuje się, że kobieta straciła na wojnie trójkę dzieci. Dwoje z nich zostało zastrzelonych na jej oczach, zaś najstarsza córka, Yoshiko, pewnego dnia nie wróciła do kryjówki. Nigdy nie znaleziono jej ciała, ale wszyscy zrozumieli, że dziewczynka nie żyje. Jedynie babcia Kamado przez cały czas czekała na jej powrót. Zobaczywszy twarz matki Misy, podobnej do zmarłej Yoshiko, uznała, że to jej dawno niewidziana córka.

Dzięki opiece Misy i jej matki babcia Kamado na pewien czas odzyskuje spokój ducha. Wystarcza jednak widok przelatującego nad polem samolotu, żeby jej stan gwałtownie się pogorszył. Załamanie nerwowe babci następuje już kolejnej nocy. Zdaje się, że kobieta na nowo przeżywa swój wojenny dramat. "Yoshiko, co się dzieje? Ani Toshiko, ani Masao się nie ruszają..." (Nakandakari 281) - mówi do Misy, tym razem to ją biorąc za swoją najstarszą córkę. Przez ułamek sekundy przerażona dziewczyna odnosi wrażenie, że rzeczywiście widzi obok staruszki dwoje leżących bez ruchu dzieci. Z pomocą matki udaje się jej uspokoić babcię, ale kolejny dzień nie przynosi poprawy. Staruszka zupełnie zamyka się w sobie, nie reaguje na próby nawiązania kontaktu i przestaje jeść. Ostatecznie krewni decydu- 
ją o przewiezieniu jej do szpitala, uznając, że nie mogą dłużej sprawiać matce Misy takiego kłopotu.

Babcia Kamado znika z życia Misy równie nagle, jak się w nim pojawiła. Nawet wówczas staruszka ma jednak niemały wpływ na wybory dziewczyny. Nękająca Misę wizja martwych dzieci sprawia, że wojna, do tej pory znana jej jedynie z opowieści, staje się dla niej bardziej rzeczywista niż kiedykolwiek wcześniej. Zmusza ją to do przemyślenia własnej postawy wobec Sił Samoobrony i podjęcia brzemiennej w skutki decyzji.

\section{Historia Misy}

W pierwszych zdaniach utworu czytelnik Matek, kobiet poinformowany zostaje o największym zmartwieniu Misy - samotności. Dziewczyna jest najstarsza z trójki rodzeństwa, a mimo to jako jedyna wciąż mieszka z matką. Ciężko orzec, czy rzeczywiście czuje się samotna, czy też chciałaby po prostu uwolnić się od złośliwych komentarzy krewnych, wytykających jej staropanieństwo i małą otwartość na ludzi. Tak czy inaczej, Misa stwierdza wprost, że „pragnie teraz tylko jednego: stać się pogodniejszą i bardziej lubianą przez mężczyzn" (Nakandakari 250).

Za pośrednictwem dalszej rodziny dziewczyna poznaje zainteresowanego nią mężczyznę, który wydaje się dobrym kandydatem na męża. Yoshikawa ma trzydzieści dwa lata i jest nauczycielem w liceum. Początkowo Misa dość sceptycznie podchodzi do pomysłu poznania go na spotkaniu zaaranżowanym przez krewnych, ale ostatecznie przystaje na ich propozycję i z lekkim podekscytowaniem zaczyna oczekiwać wyznaczonego dnia.

Mężczyzna od razu robi na niej dobre wrażenie, a z każdą chwilą jest nim coraz bardziej zauroczona. Odnosi wrażenie, że również on darzy ją sympatią. Wspólne wyjścia do kina czy do herbaciarni są dla dziewczyny nowością i sprawiają jej wielką przyjemność. Zaczyna wierzyć, że udało jej się poznać mężczyznę, z którym chciałaby wziąć ślub.

Szczęście Misy burzy jednak nieoczekiwanie Kazuko, która czuje się w obowiązku poinformować przyjaciółkę, że Yoshikawa zajmuje się też szkolnym doradztwem zawodowym i namawianiem uczniów do wstępowania do Sił Samoobrony. Początkowo dziewczyna nie zauważa w tym niczego złego, ale Kazuko nie daje za wygraną i stara się przekonać przyjaciółkę, mówiąc, że "Siły Samoobrony to wojsko. On robi z nich żołnierzy. Z licealistów. Z ludzi, którzy nawet nie są jeszcze dorośli " (Nakandakari 280). Następnie dodaje: „[...] Tu chodzi o wojnę. $\mathrm{O}$ to, czy jest się jej przeciwnikiem, czy nie. Siły Samoobrony są po to, żeby walczyć. Ich popieranie oznacza popieranie wojny" (Nakandakari 280).

Tej samej nocy pogarsza się stan babci Kamado, a Misa widzi przez chwilę zjawy dwojga zmarłych dzieci staruszki. Przygnębiona dziewczyna wkrótce do- 
chodzi do wniosku, że nie powinna wychodzić za mąż za Yoshikawę. Zwierza się ze swoich rozterek matce:

- [...] Siły Samoobrony mają prowadzić wojnę. Nawet jeśli nie teraz, to kiedyś na pewno. A co, jeżeli zginą na niej wysłani tam przez Yoshikawę uczniowie? Nie podoba mi się to.

- Głupia. Kto odrzuca swoje dzisiejsze szczęście z powodu wojny, która nie wiadomo kiedy wybuchnie? Nie będzie żadnej wojny. A nawet gdyby, to wcale jest nie powiedziane, że ci uczniowie by na niej zginęli. Zresztą nawet, jeśli profesor Yoshikawa nie wysłałby ich do Sił Samoobrony, to w razie wojny wszyscy zostaliby powołani do wojska. Dlaczego tylko profesor Yoshikawa ma być winny? W czasie wojny wszyscy są tak samo winni. Nie ma dobrych i złych.

- Jak to nie?! Przecież jest różnica między ludźmi takimi jak ty a japońskimi żołnierzami, którzy wyrzucali was ze schronów. Byliście po tej samej stronie, wszyscy ginęliście z rąk Amerykanów, ale was zabijali też Japończycy.

- To, czy się zginie na wojnie, czy nie, jest kwestią szczęścia. Przeżyją ci, którzy je mają. (Nakandakari 280)

Podczas kolejnych nocy Misę nękają wojenne koszmary. Dziewczyna postanawia osobiście spotkać się z Yoshikawą i zwierzyć mu się z prześladujących ją wizji. Mężczyzna jednak bagatelizuje jej uczucia i sugeruje, że być może jej zdrowie psychiczne nie jest $\mathrm{w}$ najlepszym stanie. Ostatecznie Misa postanawia zrezygnować z tego związku. Sprzeciw wobec wojny, będący w dużej mierze efektem poznania losów babci Kamado, okazuje się dla niej ważniejszy niż osobiste szczęście.

\section{Historia Kazuko}

Kazuko, w przeciwieństwie do Misy, nie może ignorować problemu Sił Samoobrony. Jej młodszy brat, Mamoru, postanawia zaciągnąć się do nich, mimo że ani siostry, ani rodzice nie są zadowoleni z tego pomysłu. Ojciec szybko ustępuje, matka zaś wytrwale próbuje zmienić zdanie syna i nakłonić męża do ponownego przedyskutowania problemu.

Samowolna decyzja Mamoru wpływa na życie całej rodziny. Ojciec zwykle reaguje złością na nalegania żony; zdarza mu się ją nawet uderzyć, co kobieta próbuje ukryć przed zastraszonymi córkami. Atmosfera w domu staje się coraz bardziej napięta. Matka jednak nie rezygnuje. Pierwszego dnia, zaskoczona gwałtowną reakcją męża, zaszywa się w kuchni i płacze ukradkiem. Mimo to kolejnego wieczoru ponawia swoją prośbę. Kazuko nabiera przekonania, że jej matka ma zamiar stosować tę taktykę tak długo, aż ojciec ustąpi i zgodzi się porozmawiać z synem.

Zmartwiona dziewczyna postanawia poprosić o pomoc Motokiego - mężczyznę, który kiedyś poprosił, by została jego żoną. Ma nadzieję, że może jemu uda 
się wytłumaczyć Mamoru, iż wstąpienie do Sił Samoobrony jest złym pomysłem. $\mathrm{Ku}$ jej zaskoczeniu, Motoki odmawia wsparcia jej w tej sprawie, wymawiając się zapracowaniem i zbliżającymi się wyborami na sekretarza generalnego związku, w których zamierza wystartować. Kazuko, która uważa się za jego narzeczoną, jest zdumiona zarówno taką odpowiedzią, jak i jej obojętnym tonem. W kolejnej rozmowie z mężczyzną przekonuje się, jak wielkim błędem było zwierzenie się mu $z$ rodzinnych kłopotów. Motoki, upewniwszy się, że Mamoru nie zmienił decyzji, wycofuje wówczas swoją dawną prośbę. „Bo wiesz, jakby to wyglądało, gdyby człowiek pragnący $\mathrm{w}$ pełni poświęcić się działalności w związku zawodowym miał dziewczynę, której brat służy w Siłach Samoobrony...?" (Nakandakari 276) usprawiedliwia się mężczyzna.

Atmosfera w domu Kazuko nieoczekiwanie oczyszcza się po gwałtownej kłótni między jej rodzicami. Matce udaje się uświadomić ojcu, jak wielką tragedią byłaby dla niej śmierć syna na wojnie. Mamoru, po raz pierwszy zapytany o zdanie, zdradza, że chciał wstąpić do Sił Samoobrony, żeby popracować nad swoim charakterem i stać się silniejszym psychicznie człowiekiem. Przyznaje się, że w rzeczywistości wcale nie miał zamiaru zostać profesjonalnym żołnierzem. Dlatego chętnie rezygnuje $\mathrm{z}$ tego pomysłu. $\mathrm{W}$ domu na nowo zapanowuje harmonia, a stosunki między członkami rodziny układają się wręcz lepiej niż przed kłótnią. Kazuko odbudowuje więź z siostrami i zaczyna wracać wcześniej do domu zamiast spędzać każdą chwilę na zebraniach. Rezygnuje również ze związku z Motokim, choć ten - po pomyślnym rozwiązaniu problemu Mamoru - próbuje na nowo zdobyć jej sympatię.

\section{Historia małżeństwa z Tokio}

Rozmyślając nad wydarzeniami minionego dnia i zachowaniem babci Kamado, Kazuko przypomina sobie poznaną przed dwoma laty parę dziwnych staruszków. Ich spotkanie wyprzedza w czasie o dwa lata moment rozpoczęcia właściwej akcji utworu.

W przeciwieństwie do starego mężczyzny, który od początku bardzo uprzejmie odnosi się do Kazuko, jego żona sprawia wrażenie osoby dość nieokrzesanej, momentami wręcz impertynenckiej. Przez długi czas jest pogrążona w milczeniu i ani słowem nie dziękuje Kazuko za zaproszenie do własnego domu, choć bez zażenowania korzysta z jej gościnności. Mężczyzna, jakby starając się wynagrodzić Kazuko i jej matce nieuprzejmość żony, przyjaźnie opowiada o wydarzeniach, które przywiodły ich na Okinawę. Kobiety dowiadują się wówczas, że para straciła na wojnie jedynego syna i zamierzała wziąć udział w corocznych uroczystościach żałobnych upamiętniających poległych. Podjęcie tej decyzji przyszło babci $\mathrm{z}$ wielkim trudem i zmieniła ją $\mathrm{w}$ ostatniej chwili. Postanowiła przebyć trasę 
z Mabuni do kwatery głównej śladami zmarłego syna, ale po przejściu jej krótkiego fragmentu oboje staruszkowie byli już tak wycieńczeni upałem, że skryli się w cieniu drzewa, pod którym znalazła ich Kazuko.

Dopiero po zamilknięciu mężczyzny jego żona rozpoczyna własną opowieść o wiele bardziej nieprzyjemną i - w odczuciu Kazuko - niesprawiedliwą. Babcia przyznaje wprost, że nienawidzi Okinawy, przez którą jej syn musiał zginąć. Ponure miny autochtonów obserwowanych z okna hotelu traktuje prawie jak obrazę pamięci zmarłego. Stwierdza otwarcie: „Przyglądałam się ich twarzom, ale nie zauważyłam ani jednego człowieka, który sprawiałby wrażenie zadowolonego z życia. [...] Nie mogłam powstrzymać łez, kiedy pomyślałam, że to dla takich ludzi zginął mój syn" (Nakandakari 262). W jej mniemaniu mieszkańcy Okinawy, których życie okupione zostało śmiercią innych ludzi, mieli wręcz obowiązek docenienia ich ofiary i cieszenia się każdą podarowaną im chwilą.

Kazuko jako jedyna czuje się przede wszystkim dotknięta słowami staruszki. Jej matka zdaje się lepiej rozumieć ból kobiety, która straciła na wojnie dziecko i reaguje na jej opowieść głębokim współczuciem. Dzieli się także z gośćmi historią własnej matki, która nigdy nie wybaczyła sobie tego, że pozwoliła pierworodnemu synowi wziąć udział w wojnie. Wspominająca to wydarzenie Kazuko uznaje jednak, że do babci „w ogóle nie dotrze [...] to, co mówiła matka. Będzie niezmiennie nienawidzić Okinawy i przeklinać jej mieszkańców" (Nakandakari 264). Mimo to dziewczyna nie potrafi jej źle życzyć. Prawdopodobnie również ona współczuła nieszczęśliwej kobiecie, choć jako jedyna z rozmówców nie mogła pamiętać wojny i nie potrafiła podczas rozmowy uronić ani jednej łzy.

\section{Problem tożsamości}

W przeciwieństwie do Ukumy Hiyākū, bohaterowie Matek, kobiet nie muszą bezpośrednio mierzyć się z problemem własnej tożsamości. Wojenne wspomnienia i życiowe zawirowania spowodowane przez (faktycznie nieobecne) Siły Samoobrony zdominowały wszystkie przedstawione powyżej historie, stając się osią wydarzeń opowiadania. Antywojenna wymowa utworu Nakandakari Hatsu jest w pełni czytelna. Problematyka relacji japońsko-okinawskich ukazana jest niejako mimochodem i zaobserwować ją można jedynie w pozornie mało znaczących drobiazgach.

Jednym z najważniejszych elementów świata przedstawionego w Matkach, kobietach, które wskazują na stosunek Okinawczyków do Japończyków, są bezpośrednie wypowiedzi bohaterów i używane przez nich określenia. Dość uderzający jest sposób, w jaki nazywają oni członków Sił Samoobrony. Przerażona babcia Kamado mówi o "żołnierzach Yamato", używając terminu, który odnosi się do historycznego państwa istniejącego przed wiekami (prawdopodobnie u schyłku 
okresu yayoi) na terenie obecnej Japonii. Niesie on ze sobą nacjonalistyczne konotacje ze względu na liczne nawiązania do Yamato jako kolebki cesarstwa i czystej krwi Japończyków (w opozycji do m.in. Riukiuańczyków, Ajnów, Tajwańczyków etc.) w eugenicznej, przedwojennej retoryce. Co więcej, tego samego określenia używają również zdecydowanie młodsze Misa i Kazuko. Termin ten kojarzy się również z okinawskim słowem "Yamatunchu”, oznaczającym Japończyków spoza Okinawy, w przeciwieństwie do miejscowych Uchinānchu (dosł. Okinawczycy). Określenie „żołnierze Yamato" oznacza więc świadomość własnej odrębności Okinawczyków - niekoniecznie narodowej, ale na pewno historycznej i kulturowej.

Interesujące jest również uparte określanie członków Sił Samoobrony przez wszystkich bohaterów utworu mianem żołnierzy. Oficjalnie bowiem Japonia nie ma prawa do posiadania armii, co zapisane jest w kontrowersyjnym artykule dziewiątym japońskiej konstytucji (Konstytucja Japonii z 3 listopada 1946 (ttumaczenie prof. Teruji Suzuki), http://www.pl.emb-japan.go.jp/relations/konstytucja.htm):

Naród japoński, dążąc szczerze do międzynarodowego pokoju opartego na sprawiedliwości i porządku, wyrzeka się na zawsze wojny, jako suwerennego prawa narodu, jak również użycia lub groźby użycia siły, jako środka rozwiązywania sporów międzynarodowych.

Dla osiągnięcia celu określonego w poprzednim ustępie nie będą nigdy utrzymywane siły zbrojne lądowe, morskie i powietrzne ani inne środki mogące służyć wojnie. Nie uznaje się prawa państwa do prowadzenia wojny.

Z tego zapisu jasno wynika, że Japonia nie ma prawa do posiadania wojska, a Siły Samoobrony mogą służyć jedynie do ewentualnej obrony kraju. Dla bohaterów opowiadania Matki, kobiety oficjalne nazewnictwo nie ma jednak znaczenia. $\mathrm{W}$ ich rozumieniu członkowie Sił Samoobrony są żołnierzami - w dodatku żołnierzami obcymi, przybyłymi z odległych ziem. Znamienny jest fakt, że protest babci Kamado, do którego przyłączają się potem związkowcy, dotyczy nie jakichkolwiek działań wojskowych, lecz - jak mogłoby się zdawać - niewinnej, bezinteresownej pomocy w czasie żniw. Dla starej kobiety, która straciła na wojnie całą najbliższą rodzinę, nawet sam fakt wejścia japońskich żołnierzy na jej pole jest nie do przyjęcia i napawa ją strachem. Związkowcy $\mathrm{z}$ kolei upatrują $\mathrm{w}$ tym podstępnej próby przekonania miejscowej ludności o swoich dobrych intencjach i przeciągnięcia ich na swoją stronę.

Zachowanie Japończyków podczas wojny również kładzie się cieniem na japońsko-okinawskich relacjach. Misa, podczas sprzeczki z matką, wspomina żołnierzy, którzy wyrzucali cywilów z kryjówek, tym samym narażając ich na śmierć. Dziewczyna oskarża ówczesnych Japończyków o mordowanie miejscowej ludności, mimo że walczyła ona po tej samej stronie, czyli przeciw amerykańskiemu najeźdźcy. Jej słowa dowodzą, że pamięć o tych wydarzeniach przetrwała nawet wśród młodego pokolenia, które urodziło się już po wojnie. 
Historia pary opłakujących syna tokijczyków, a zwłaszcza przepełnionej nienawiścią babci, wzbogaca utwór o punkt widzenia drugiej strony. Dzięki opowieści kobiety czytelnik może poznać również problemy wynikające ze stosunku Japończyków do Okinawczyków. Pochodząca ze stolicy staruszka traktuje Okinawę jak odrębne państwo, z którym w żaden sposób nie czuje się związana. Uważa, że jej syn "zginął w tak odległym miejscu, dla zupełnie obcych ludzi" (Nakandakari 262). Nie czuje się dumna z tego, że umarł dla kraju, walcząc w obronie ojczyzny i rodaków. Okinawczycy są dla niej obcy i nie solidaryzuje się $\mathrm{z}$ nimi nawet $\mathrm{w}$ najmniejszym stopniu.

Wspominając parę tokijskich bohaterów utworu Matki, kobiety, należy również odnotować spostrzeżenie Kazuko, która za pierwszym razem widziała ich jedynie przelotnie, podczas jazdy samochodem, a mimo to od razu uznała, że „wyglądali na małżeństwo, które przyleciało z właściwej Japonii" (Nakandakari 260). Najwyraźniej nawet strój odróżniał Yamatunchu od Uchinānchu.

Warto również wspomnieć o roli języka okinawskiego w utworach Posterunkowy Ukuma i Matki, kobiety. W pierwszym utworze używa go matka tytułowego bohatera, jego ukochana, Mała Kamarū, oraz jej brat. W dialekcie zapisana jest również piosenka, którą śpiewają zmęczone upałem dzieci. To, że Hiyākū wypowiada się - jak jego współpracownicy - w standardowym języku japońskim (jap. hyōjungo), jest jeszcze jednym dowodem na jego próbę zjaponizowania samego siebie. W przypadku Matek, kobiet natomiast można zaobserwować, jak z każdym pokoleniem posługiwanie się dialektem staje się coraz mniej powszechne. Babcia Kamado wypowiada się wyłącznie po okinawsku. Matka Kazuko używa tego języka jedynie $\mathrm{w}$ chwili największego wzburzenia, kiedy to przekonuje męża, że nigdy nie zgodzi się na wstąpienie Mamoru do Sił Samoobrony. Z kolei Misa i Kazuko rozmawiają ze sobą tylko w standardowym języku japońskim. Te zmiany pokoleniowe można traktować jako dowód stopniowej asymilacji Okinawczyków i zanikania jednego z istotnych elementów ich tożsamości narodowej.

\section{Podsumowanie}

Ikemiyagi Sekihō opisał w Posterunkowym Ukumie sytuację panującą na Okinawie krótko po zaanektowaniu królestwa Riukiu i problemy wynikające z dość oczywistych różnic między ówczesnymi Japończykami a Okinawczykami. Matki, kobiety autorstwa Nakandakari Hatsu stanowią zaś interesujący zapis stosunków okinawsko-japońskich na przełomie lat siedemdziesiątych i osiemdziesiątych XX wieku, a więc około stu lat po upadku królestwa. Problemy z określeniem własnej tożsamości znacząco straciły na intensywności przez czas, który upłynął pomiędzy obiema publikacjami. Bohaterki Matek, kobiet nie muszą, jak Hiyākū, wybierać pomiędzy okinawskością a japońskością, a kontrast pomiędzy obiema 
grupami nie jest aż tak wyraźny jak w przypadku Posterunkowego Ukumy. Mimo to nietrudno dostrzec panujący między nimi dystans, a czasami nawet niechęć i nieufność. Dzięki obu opowiadaniom czytelnik może prześledzić zmiany w podejściu Okinawczyków do kwestii własnej odrębności narodowej, a także przyjrzeć się historii stosunków okinawsko-japońskich w XX wieku widzianych oczami zwykłych ludzi. Problematyka ta stanowi zaledwie jeden $z$ tematów poruszanych przez współczesnych pisarzy okinawskich, nie ograniczających się jedynie do zagadnień związanych bezpośrednio z ich ojczyzną, ale mimo to wciąż bywa przez nich poruszana.

\section{BIBLIOGRAFIA}

Ambasada Japonii w Polsce. „Konstytucja Japonii z 3 listopada 1946 (tłumaczenie Teruji Suzuki)”. 1946. Web. 17.08.2016. <http://www.pl.emb-japan.go.jp/relations/konstytucja.htm>

Honda, Erumi. Hearing Voices. Female Transmission of Memories in Okinawan Literature in the 1970s and 1980s. Massachusetts: [brak wydawnictwa], 2010.

Ikemiyagi, Sekihō. „Ukuma junsa”. Okinawa bungaku zenshū. T. 6. Ed. Okinawa bungaku zenshū henshū iinkai. Tōkyō: Kokusho Kankōkai, 1990.

Kawamura, Minato, red. Gendai Okinawa bungaku sakuhin sen. Tōkyō: Kōdansha, 2011.

Kerr, George. Okinawa. The History of an Island People. Boston: Tuttle Publishing, 2000.

Maher, John C. „North Kyushu Creole: A Language-Contact Model for the Origins of Japanese”. Multicultural Japan. Palaeolithic to Postmodern. Ed. D. Denoon, M. Hudson, G. McCormack, T. Morris-Suzuki. Hong Kong: Cambridge University Press, 1996.

Masanori, Nakahodo. „Ukuma junsa: sakuhin kaisetsu”. Okinawa bungaku sen. Nihon bungaku no ejji kara no toi. Ed. K. Okamoto, T. Takahashi. Tōkyō: Bensei shuppan, 2003.

Molasky Michael, Rabson Steve. Southern Exposure. Modern Japanese Literature from Okinawa. Honolulu: University of Hawaii Press, 2000.

Morris-Suzuki,Tessa. „A Descent into the Past: The Frontier in the Construction of Japanese Identity”. Multicultural Japan. Palaeolithic to Postmodern. Ed. D. Denoon, M. Hudson, G. McCormack, T. Morris-Suzuki. Hong Kong: Cambridge University Press, 1996.

Morton, Leith. „Yuta as the postcolonial Other in Öshiro Tatshuhiro's fiction”. Representing the Other in Modern Japanese Literature. A critical approach. Ed. R. Hutchinson, M. Williams. London: Routledge, 2007.

Nakandakari, Hatsu. „Haha tachi, onna tachi”. Okinawa bungaku zenshū. T. 8. Ed. Okinawa bungaku zenshū henshū iinkai. Tōkyō: Kokusho Kankōkai, 1990.

Okamoto, Keitoku, Takahashi Toshio, eds. Okinawa bungaku sen. Nihon bungaku no ejji kara no toi. Tōkyō: Bensei shuppan, 2003.

Pearson, Richard. „The Place of Okinawa in Japanese Historical Identity”. Multicultural Japan. Palaeolithic to Postmodern. Eds. D. Denoon, M. Hudson, G. McCormack, T. Morris-Suzuki. Hong Kong: Cambridge University Press, 1996. 
